\title{
Penegakan Hukum Perdagangan Perempuan (Trafficking In Women) Diwilayah
}

\section{Hukum Pengadilan Negeri Pekanbaru}

M Fadly daeng Yusuf.

Fakultas Hukum, Universitas Lancang Kuning, Pekanbaru, Indonesia, Email : fadlydaeng@unilak.ac.id

\section{Article Info}

Article History:

Received : 07-02-2021

Revised : 20-05-2021

Accepted : 10-07-2021

Published : 28-11-2021

\section{Keywords:}

Keyword 1 : enforcement Keyword 2 : Trafficking in women

Keyword 3 : Court

\section{Informasi Artikel}

\section{Histori Artikel:}

Diterima : 07-02-2021

Direvisi : 20-05-2021

Disetujui : 10-07-2021

Diterbitkan : 28-11-2021

\section{Kata Kunci:}

Kata Kunci : Penegakan

Kata Kunci : Perdagangan

Perempuan

Kata Kunci : Pengadilan

\begin{abstract}
There are several obstacles that cause the crime of trafficking in women to continue to occur, namely due to the economic crisis and the low moral crisis of criminal sanctions. As a law enforcement agency, the Pekanbaru District Court functions to examine, decide, and resolve cases, one of which is criminal cases for people seeking Justice in the Pekanbaru Region). This study on the law enforcement of trafficking in women (Trafficking in women) in the Pekanbaru District Court consists of two main problems, namely: 1 . How is the law enforcement of the crime of trafficking in women in the Pekanbaru District Court?, What is the settlement procedure in law enforcement of trafficking in women in the Pekanbaru District Court area? what happened in the decision at the Pekanbaru District Court. Sources of data come from primary data, namely case files, PTTPO Law, Criminal Code, Criminal Procedure Code.

\section{Abstrak}

Terdapat beberapa kendala yang menyebabkan tindak pidana perdagangan perempuan masih terus saja terjadi, yaitu diakibatkan krisis ekonomi dan krisis moral rendahnya sanksi pidana,.Sebagai lembaga penegak hukum adalah Pengadilan Negeri Pekanbaru berfungsi untuk memeriksa, memutus, dan menyelesaikan perkara salah satunya perkara pidana untuk rakyat pencari keadilan di Wilayah Pekanbaru).Penelitian ini tentang Penegakan hukum perdagangan perempuan (Trafficking in women) diwilayah Pengadilan negeri Pekanbaru terdiri dari dua masalah pokok yaitu : 1.Bagaimana penegakan hukum tindak pidana perdagangan perempuan (trafficking in women) di wilayah Pengadilan Negeri Pekanbaru?, Bagaimana prosedur penyelesaian dalam penegakan hukum perdagangan perempuan (trafficking in women) di wilayah Pengadilan Negeri Pekanbaru?Untuk mendukung penelitian tersebut,penulis menggunakan metodelogi penelitian Hukum yuridis normatif dan Sosiologis dimana penelitian untuk melihat korelasi antara hukum dengan masyarakat yang terjadi dalam putusan di Pengadilan Negeri Pekanbaru. Sumber data berasal dari data primer yaitu berkas perkara,UU PTTPO,KUHP,KUHAP. 


\section{PENDAHULUAN}

Perdagangan orang merupakan salah satu jalur terjadinya perdagangan orang yang korbanya rata-rata berada dibawah garis kemiskinan,khususnya perempuan. Apalagi hingga saat ini posisi perempuan masih termarjinalisasi yang secara langsung dan tidak langsung akan mempengaruhi kondisi perempuan.Situasi semacam ini merupakan santapan sindikat perdagangan perempuan dan anak yang terorganisir untuk melakukan perekrutan.Bahkan nyaris jauh dari jangkauan hukum, karena sindikatnya diawali dengan transaksi utang piutang antara pemasok tanaga kerja illegal dengan korban yang mempunyai bayi atau anak perempuan yang masih perawan,sehingga jika korban tidak mampu untuk menyelesaikan transaksi yang telah disepakati, maka agunannya adalah perempuan yang masih dibawah umur atau perawan. ${ }^{1}$

Biasanya mereka dibawa keluar kota dan dijanjikan pekerjaan dengan gaji tinggi. Adakalanya oleh calo korban dan keluarganya korban sudah dimintai uang atau diberi status berutang. Pada saat bersamaan, juga terjadi pemalsuan Kartu Tanda Penduduk agar korban dianggap cukup umur. Dalam tahap ini ada juga anak-anak yang memang sengaja dijual oleh orang tuanya, atau paling tidak orang tuanya mendapat sejumlah uang sebagai pengganti izin bagi kepergian anaknya. Konsep budaya fillial piety, yaitu kewajiban anak untuk berbakti kepada orang tua,menjadi faktor pendorong keluarnya seoarang anak dari tempat tinggalnya. Anak tidak memiliki posisi tawar untuk menolak kehendak orang tua. Dalam tahap kedua, korban dipaksa tinggal ditempat penampungan yang sangat tidak layak. Kartu identitas dan semuanya uangnya diambil sehingga korban terpaksa tinggal dan tidak bisa melarikan diri. Kemudian korban dipindahtangankan dari satu calo kecalo yang lain, dengan diikuti sejumlah transaksi pembayaran. Tahap berikut korban diberi pekerjaan sebagai buruh kasar, pekerja seks komersial untuk bisnis

Kita harus akui bahwa perdagangan orang di Indonesia tidak hanya terjadi di zaman modern tetapi sudah terjadi sejak zaman raja-raja Jawa dahulu, perempuan merupakan bagian pelengkap dari sistem pemerintahan feodal. Pada masa itu, konsep kekuasaan

\footnotetext{
${ }^{1}$ Sulistyowati Irianto, et.al, 2007. Perdagangan Perempuan Dalam Peredaran Narkotika. Jakarta: Yayasan Obor Indonesia hal 3
} 
seorang raja digambarkan sebagai yang agung dan mulia. Raja mempunyai kekuasan penuh, antara lain tercermin dari banyaknya selir yang dimilikinya. Beberapa orang dari selir tersebut adalah putri bangsawan yang diserahkan kepada raja sebagai tanda kesetiaan, sebagian lagi persembahan dari kerajaan lain, tetapi ada juga yang berasal dari lingkungan kelas bawah yang dijual atau diserahkan oleh keluarganya dengan maksud agar keluarga tersebut mempunyai keterkaitan langsung dengan keluarga istana. $^{2}$

Pengaturan dan ancaman sanksi terkait perdagangan manusia tidak terkecuali kelompok rentan yakni perempuan sudah di atur secara khusus di dalam Undangundang Nomor 21 Tahun 2007 tentang Tentang Pemberantasan Tindak Pidana Perdagangan Orang.

Adanya kekhawatiran munculnya berbagai bentuk manipulasi dan exploitasi manusia, khususnya terhadap perempuan sebagai akibat maraknya kejahatan perdagangan manusia memang bukan tanpa alasan. Banyak contoh yang dapat diberikan perempuan dan anak-anak, yang seharusnya memperoleh perlakuan yang layak justru sebaliknya dieksploitasi untuk tujuan-tujuan tertentu. Padahal, perempuan adalah ciptaan Tuhan Yang Maha Kuasa perlu dilindungi harga diri dan martabat nya serta dijamin hak hidupnya untuk tumbuh dan berkembang sesuai fitrah dan kodratnya.

Upaya perlindungan hukum terhadap perempuan, salah satunya melalui pencegahan dan pemberantasan perdagangan manusia, perlu secara terus menerus dilakukan demi tetap terpeliharanya sumber daya manusia yang berkualitas. Kualitas perlindungan terhadap perempuan dan anak hendaknya memiliki derajat/tingkat yang sama dengan perlindungan terhadap orang-orang dewasa maupun pria, karena setiap orang memiliki kedudukan yang sama di depan hukum (equality before the law).

\section{ANALISIS DAN PEMBAHASAN 1}

Penegakan Hukum tindak pidana perdangangan perempuan (Trafficking in women) di Wilayah Pengadilan Negeri Pekanbaru.

\footnotetext{
${ }^{2}$ Zaelani Tammaka, 2003, Menuju Jurnalisme Berperikemanusiaan Kasus Trafficking dalam Liputan Media di Jawa Tengah dan DIY, Aji Surakarta, Surakarta, hal. 3.
} 
Dalam menanggulangi pemberantasan tindak pidana perdagangan orang yang terjadi Kota Pekanbaru maka Pengadilan Negeri Pekanbaru melakukan tindakan preventif dan tindakan represif, dari tindakan tersebut dapat penulis uraikan sebagai berikut:

\section{Tindakan Preventif}

Penegakan hukum secara preventif yang dilakukan adalah sebagai berikut :

a. Berkoordinasi dengan instansi-instansi Pemerintahan Daerah setempat mengadakan Seminar-Seminar Hukum yang berkaitan tentang Tindak Pidana Perdagangan Orang yang ditujukan kepada mahasiswa dan masyarakat di Pekanbaru.

b. Bekerja sama dengan aparat penegak hukum lainya seperti kepolisian dan kejaksaan melakukan Penyuluhan-Penyuluhan Hukum yang berkaitan dengan tindak pidana perdagangan orang yang ditujukan kepada pelajar, mahasiswa maupun masyarakat.

c. Mengadakan Pelatihan-Pelatihan Hukum yang ditujukan kepada aparat penegak hukum lainya

\section{Tindakan Represif}

Tindakan represif yang dilakukan oleh Pengadilan Negeri Pekanbaru bila tindakan preventif yang dilakukan tidak efektif, maka hukum harus ditegakan dengan menerapkan ketentuan-ketentuan yang berlaku terhadap pelaku tindak pidana perdagangan perempuan dibawah umur,tindakan tersebut dilakukan guna mengungkap sindikat perdagangan perempuan dibawah umur dengan sanksi yang tegas dan konsisten sehingga dapat membuat jera para pelaku tindak pidana perdagangan perempuan tersebut.

\section{Penegakan Hukum}

Penegakan hukum adalah proses dilakukannya upaya untuk tegaknya atau berfungsinya norma-norma hukum secara nyata sebagai pedoman perilaku dalam lalu lintas atau hubungan hukum dalam kehidupan bermasyarakat dan bernegara. Proses penegakan hukum pidana dilakukan oleh suatu sistem yaitu yang disebut dengan Sistem Peradilan Pidana yaitu mekanisme kerja dalam usaha penanggulangan kejahatan dengan mempergunakan dasar pendekatan sistem. Sistem penanggulangan kejahatan itu dilakukan oleh komponen-komponen yang saling bekerjasama, yaitu instansi atau badan 
yang kita kenal dengan nama kepolisian, kejaksaan, pengadilan dan lembaga pemasyarakatan ${ }^{3}$.

Masing-masing komponen atau sub system mempunyai tugas dan output sendirisendiri sesuai dengan funsi dan wewenangnya masing-masing. Kepolisian bertugas melakukan penyidikan dan akan menghasilkan suatu out-put yang disebut dengan berita acara pemeriksaan (BAP). Kejaksaan berdasarkan BAP dari Kepolisian bertugas melakukan penuntutan dengan suatu surat dakwaan dan selanjutnya Pengadilan berdasarkan surat dakwaan dari Kejaksaan akan mengadili perkara kemudian menjatuhkan putusan. Lembaga Pemasyarakatan bertugas melakukan pembinaan terhadap nara pidana agar dapat kembali menjadi orang baik dalam masyarakat.

Pelaksanaan penegakan hukum pidana yang sangat menarik perhatian publik saat sekarang adalah mengadili perkara dan penjatuhan putusan oleh Pengadilan. Putusan yang dijatuhkan Pengadilan kadang-kadang dianggap masyarakat jauh dari rasa keadilan. Bahkan tidak jarang setelah putusan diucapkan, masyarakat mencari-cari kesalahan materi putusan/pertimbangan putusan atau legal reasoning dari putusan tersebut. Ada juga pihak-pihak yang berperkara yang tidak setuju dengan bunyi putusan minta supaya hakim yang memutus perkara dilaporkan ke Komisi Yudisial karena kesalahan dalam proses pelaksanaan persidangan dan dalam memutus perkara. Kesalahan tersebut sebenarnya menurut ketentuan hukum acara, bagi pihak yang tidak menerima putusan karena dirasa tidak adil, dapat mengajukan upaya hukum ke Pengadilan yang lebih tinggi seperti banding ke Pengadilan Tinggi atau kasasi ke Mahkamah Agung.

Sesungguhnya pengambilan putusan dalam perkara pidana di Pengadilan dilakukan oleh hakim yang independen melalui suatu proses persidangan. Proses tersebut ikut andil dalam menentukan bagaimana putusan yang akan dijatuhkan. Sebaliknya putusan yang dirasakan adil oleh masyarakat sangat tergantung juga dari proses persidangan yang adil, taransparan dan dapat dipertanggungjawabkan.

Dalam makalah ini penulis akan membahas bagaimana peran kemandirian pengadilan dalam penegakan hukum dan keadilan serta bagaimana proses perkara pidana dilakukan, mulai disidangkannya suatu perkara sampai putusan diucapkan yang

\footnotetext{
${ }^{3}$ Satjipto Raharjo,2010,penengakan hukum progrengsif,PT Kompas,Jakarta,Hal 57
} 
diharapkan putusan tersebut mengandung nilai-nilai keadilan yang didambakan masyarakat pencari keadilan (yustisiabelen).

\section{Kemandirian Hakim Pengadilan}

Didalam suatu negara hukum kekuasaan kehakiman(yudikatif) merupakan badan yang sangat menentukan terhadap substansi dan kekuatan kaidah-kaidah hukum positif termasuk hukum pidana. Karena melalui badan inilah konkritisasi hukum positif dilakukan oleh hakim pada putusan-putusannya di depan pengadilan. Dengan ungkapan lain dapat dikatakan, bahwa bagaimanapun baiknya segala peraturan hukum pidana yang diciptakan dalam suatu negara, dalam usaha penanggulangan kejahatan, akan tetapi peraturan-peraturan itu tidak ada artinya apabila tidak ada kekuasaan kehakiman yang dilakukan oleh hakim yang mempunyai kewenangan untuk memberi isi dan kekuatan kepada norma-norma hukum pidana tersebut ${ }^{4}$.

Disini tampaklah bahwa pengadilan/hakim sebagai pelaksana kekuasaan kehakiman merupakan tumpuan dari segala lapisan masyarakat pencari keadilan (yustisiabelen) untuk mendapat keadilan serta menyelesaikan persoalan-persoalan tentang hak dan kewajibannya masing-masing menurut hukum. Oleh karenanya dapatlah dimaklumi akan adanya dan terselenggaranya peradilan yang baik, teratur serta memenuhi rasa keadilan masyarakat. Penyelenggaraan peradilan itu dilakukan oleh kekuasaan kehakiman yang merdeka dan pengadilan/hakim yang bebas, guna menegakkan hukum dan keadilan berdasarkan Pancasila.

Tugas hakim adalah sebagai pelaksana Kekuaasaan Kehakiman yang merdeka untuk menyelenggarakan peradilan guna menegakkan hukum dan keadilan, yang pada dasarnya adalah mengadili. Kata mengadili merupakan rumusan yang sederhana, namun di dalamnya terkandung pengertian yang sangat mendasar, luas dan mulia, yaitu meninjau dan menetapkan sesuatu hal secara adil atau meberikan keadilan. Pemberian keadilan tersebut harus dilakukan secara bebas dan mandiri. Untuk dapat mewujudkan fungsi dan tugas hakim tersebut, penyelenggaraan peradilan harus bersifat teknis profesional dan non politis serta non partisan. Peradilan dilakukan sesuai standar profesi

\footnotetext{
${ }^{4}$ Prof.Dr.RM.Sudikno Mertakusumo.SH,Artikel Hukum,Kemandirian Hakim ditinjau dari struktur lembaga kehakiman,24 maret 2008
} 
berdasarkan ketentuan hukum yang berlaku, tanpa pertimbangan-pertimbangan politis dan pengaruh kepentingan pihak-pihak ${ }^{5}$.

Dari uraian dan pandangan diatas maka penegakan hukum dan keadilan inilah yang menjadi dasar filosofi dari kemandirian hakim ini. Mengingat dasar filosofi untuk menegakkan hukum dan keadilan inilah, maka kepada hakim perlu diberi kebebasan dari pengaruh kekuasaan ektra judisial dalam melaksanakan fungsi dan kewenangan kekuaaan kehakiman. Akan tetapi kebebasan itu harus disadari hanya merupakan kebebasan yang diberikan undang-undang atau hukum (legal right) bukan kebebasan yang bersifat alami (natural right).

Sebagai landasan filosofi dari kebebasan hakim, keadilan itu sendiri mempunyai makna yang begitu kaya, sehingga selalu menimbulkan perbedaan dan petentangan dalam menafsirkannya. Walaupun demikian kiranya diusahakan suatu pemahaman yang pokok dan mendasar sehingga dapat disepakati oleh banyak pihak bahwa keadilan itu menjadi tujuan yang hendak dicapai dari kemandirian hakim dalam melaksanakan persidangan. ${ }^{6}$ Plato menegaskan bahwa makna pokok dari keadilan adalah kemampuan memperlakukan setiap orang sesuai dengan haknya masing-masing.[3] Pemahaman ini diteruskan sepanjang sejarah kebudayaan Barat melalui Aristoteles, Cicero, Agustinus dan terutama oleh sistem hukum Romawi yang masih punya pengaruh kuat sampai dewasa ini. Meskipun pemahaman keadilan cukup singkat dan jelas tetapi dalam pelaksanaannya sering timbul kesukaran praktis, karena masih dipertanyakan sejauh mana hak orang itu. Manakah hak orang itu dan dari mana datangnya hak itu. Tanpa memberikan kejelasan seperti itu tindakan yang dimaksudkan sebagai pemberian keadilan, ternyata malah merupakan ketidak adilan.

Oleh karenanya kemudian dikatakan keutamaan keadilan terwujud pada tindakan-tindakan kepada orang lain, yakni orang yang memiliki hak atas perlakuan itu. Hal itu antara lain ditegaskan oleh Thomas Aquinas dengan rumusan "keadilan adalah untuk orang lain”.[4] Perlakuan yang adil dilaksanakan bukan karena kasih sayang, hubungan perasaudaraan atau perasahabatan dan sebagainya, melainkan kerena pengakuan atas hak orang lain.

\footnotetext{
${ }^{5}$ www.http//tugas hakim 2011,diakses pada Desember 2014

${ }_{6}^{6}$ Antonius Sujata,Kompas (dalam Reformasi penengakan hukum),Djambatan,Jakarta 2000
} 
Pengertian keadilan ini pada perode akhir-akhir ini banyak ditinjau dari berbagai sudut pandang. Ada yang melihat dari segi keadilan legal (legal justice) yaitu keadilan yang sesuai dengan hukum. Pandangan ini dapat dilihat dari peraturan perundangundangan yang berlaku dan dari putusan hakim pengadilan yang mencerminkan keadilan hukum negara dalam bentuk formal. Akan tetapi adil tidaknya suatu peraturan perundang-undangan atau putusan hakim sangat pula ditentukan oleh representasi keadilan moral (moral justice) dan keadilan sosial (social justice), sebagai dua sudut pandang yang lain melihat keadilan itu sendiri. ${ }^{7}$

Keadilan moral (moral justice) tidak lain dari keadilan yang berdasarkan moralitas yang berbicara tentang baik dan buruk. Moralitas berasal dari berbagai sumber, yang terpenting disini adalah agama. Agamalah yang menetapkan tentang norma-norma baik dan buruk, benar dan salah, adil dan tidak adil. Perundang-undangan Indonesia sangat mendukung keadilan hukum yang berdasarkan keadilan moral agama. Ini terlihat secara umum dari pasal 2 ayat (1) UU No. 48 tahun 2009 yang menyatakan: Peradilan dilakukan "DEMI KEADILAN BERDASARKAN KETUHANAN YANG MAHA ESA". Setiap putusan hakim harus memuat kata-kata tersebut sebagai kepala putusannya. Putusan hakim yang tidak memuat kata-kata tersebut diatas diancam batal demi hukum. ${ }^{8}$

Melalui Undang-Undang pemberantasan tindak pidana perdagangan orang ini diharapkan praktik perdagangan orang dapat diberantas karena Undang-Undang ini telah secara jelas mengatur sanksi tegas bagi pelaku perdagangan orang, mulai dari pidana penjara yang lebih berat hingga denda yang tinggi untuk mewujudkan harapan itu. UU PTPPO juga memberi jaminan perlindungan yang lebih baik kepada para korban. Sesuai undang-undang ini korban tindak perdagangan orang akan mendapat pelayanan pemulihan fisik dan psikis dari pemerintah. Pelaku perdagangan orang yang diputus bersalah oleh pengadilan juga diberi kewajiban membayar ganti rugi baik materiil maupun immaterial sesuai dengan tuntutan korban. Nilainya bisa mencapai ratusan juta rupiah. Jika pelakunya adalah korporasi, misal PJTKI yang biasanya

\footnotetext{
${ }^{7}$ Satjipto Raharjo,Penengakan Hukum Suatu Tinjauan Sosiologis,Genta Publishing,2011

8 Ibid HIm 116
} 
berkaitan dengan pengiriman TKI keluar negeri maka menurut pasal 15 UU PTPPO dendanya bisa mencapai 3(tiga) kali lipat dari pelaku individual. ${ }^{9}$

Selain sanksi denda, ancaman pidana penjara bagi pelaku individu yang terlibat praktik perdagangan orang mencapai 15 tahun. Ini jauh lebih tinggi dari delik serupa dalam KUHP pasal 297 yang hanya 6 tahun penjara. Sanksi pidana dan denda yang berat ini tentu akan membuat orang atau perusahaan berpikir panjang untuk melakukan praktek perdagangan orang. Undang-undang No.21 Tahun 2007 ini selain memuat adanya ketentuan ancaman pidana yang berat bagi pelakunya juga terdapat pula ketentuan tentang proses perkara pidana perdagangan orang dipersidangan yaitu bab IV tentang penyelidikan, penyidikan, penuntutan dan pemeriksaan disidang pengadilan yang memuat pasal 28 sampai dengan pasal 42 yang diharapkan dapat melengkapi undang-undang tentang hukum acara pidana yang telah ada sekarang ini.

Adanya Undang-undang No.21 Tahun 2007 tentang PTPPO,selain untuk mencegah dan menangani perdagangan orang juga melindungi korban dan akibat tindak pidana perdagangan orang. Disamping itu, ditetapkannya UU ini dimaksudkan untuk mewujudkan komitmen nasional terhadap keinginan bangsa-bangsa internasional dalam memberantas tindak pidana perdagangan orang karena sifat tindak pidananya yang transnasional dan terorganisir. Tegasnya,Undang-undang ini dapat memberikan kepastian hukum kepada semua pihak, aparat penegak hukum, pemerintah dan masyarakat luas.

Keberadaan undang-undang PTPPO jelas memerlukan dukungan Pemerintah yaitu dengan Keppres RI No.88 Tahun 2002 tentang Rencana Aksi Nasional Penghapusan Perempuan dan Anak yang menyatakan perdagangan perempuan dan anak adalah segala tindakan pelaku yang mengandung salah satu atau lebih tindakan perekrutan, pengangkutan antar daerah dan antar negara, pemindah tanganan,pemberangkatan, penerimaan dan penampungan sementara atau ditempat tujuan dengan cara ancaman,penggunaan kekerasan fisik, penculikan,penipuan,tipu muslihat,memberikan pembayaran atau keuntungan,dimana perempuan dan anak digunakan untuk tujuan pelacuran dan eksploitasi seksual, buruh migran legal maupun

\footnotetext{
${ }^{9}$ Kitab undang-undang Hukum Pidana,pasal 297
} 
ilegal,adopsi anak, pengantin pesanan,pembantu rumah tangga, mengemis, industri pornografi, pengedaran obat terlarang, dan penjualan organ tubuh, serta bentuk-bentuk eksploitasi lainya. Adanya Peranturan Pemerintah Pusat dan Daerah yang meliputi aspek perlindungan saksi dan korban, aspek pencegahan dan penanganan serta aspek kerjasama dan peran serta masyarakat.Adanya keputusan presiden dan peraturan daerah tersebut diharapkan dapat mengimplementasikan Undang-undang Pemberantasan Tindak Pidana Perdagangan orang secara utuh yang meliputi pencegahan,penegakan hukum dan perlindungan korban tindak pidana perdagangan orang.

Impelementasi dari undang-undang No.21 Tahun 2007 Tentang PTPPO tersebut adalah undang-undang ini dapat dilaksanakan didaerah. Sebagaimana terlihat dalam pasal-pasalnya, undang-undang ini bersifat mengikat seluruh warga negara Indonesia, namun dalam pelaksanaan didaerah semuanya bergantung kepada kondisi daerah masing-masing seperti diwilayah pengirim (sending area) dari perdagangan orang tentu memiliki kekhasan dalam menjabarkan esensi dari undang-undang ini dibandingkan dengan wilayah penerima (receiving area). Dengan kata lain perangkat hukum perdagangan orang secara nasional perlu didukung dengan adanya peraturan daerah yang mendukung program anti perdagangan orang.

\section{ANALISAN DAN PEMBAHASAN 2}

\section{Prosedur Penyelesaian dalam penegakan hukum perdagangan wanita (Traffiking in women) di Pengadilan Negeri Pekanbaru}

Sebelum Pengadilan/Hakim sampai kepada pengambilan putusan dalam setiap perkara pidana yang ditanganinya, terlebih dahulu melalui proses pemeriksaan persidangan yang merupakan tahap-tahap dalam pemeriksaan itu. Tanpa melalalui proses pemeriksaan persidangan ini hakim tidak akan dapat mengambil putusan dalam perkara pidana yang ditanganinya, karena hanya dengan melalui proses inilah akan didapatkan peristiwa konkrit yang dilakukan terdakwa. Melalui proses persidangan ini pula semua pihak, baik jaksa penuntut umum maupun terdakwa / penasehat hukum diberi kesempatan yang sama untuk mengemukakan pendapatnya serta menilai hasil pemeriksaan persidangan menurut perspektifnya masing-masing. Pada akhir dari proses pemeriksaan persidangan hakim akan mengambil putusan. Proses persidangan ini 
merupakan salah satu aspek yuridis formil yang harus dilakukan hakim untuk dapat mengambil putusan dalam perkara pidana. ${ }^{10}$

Proses pemeriksaan persidangan perkara pidana di Pengadilan yang dilakukan oleh hakim secara umum diatur dalam Kitab Undang-Undang Hukum acara pidana disingkat dengan sebutan KUHAP ( Undang-undang No. 8 tahun 1981 ) dan beberapa peraturan pelaksanaan lainnya, seperti PP No. 27 tahun 1983 tentang pelaksanaan KUHAP dan Peraturan Menteri Kehakiman RI No. M.06.UM.01.06 tahun 1983 tentang tata tertip dan tata ruang sidang. Disamping itu dalam praktek seringkali pelaksanaan tahap-tahap dan tata cara persidangan disesuaikan dengan keadaan berdasarkan kebijakan hakim / ketua majelis hakim atau atas kesepakatan antara pihak-pihak yang terkait dalam pemeriksaan perkara pidana, sejauh tidak menyimpang dari asas dan tujuan pemeriksaan perkara pidana. ${ }^{11}$

\section{Sidang Pembacaan Surat Dakwaan, Eksepsi dan Putusan Sela}

Pada hari sidang yang telah ditetapkan oleh hakim/majelis hakim, sidang pemeriksaan perkara pidana oleh ketua majelis hakim dibuka dan dinyatakan terbuka untuk umum kecuali dalam perkara mengenai kasulilaan atau terdakwanya anak-anak. Pemeriksaan itu dilakukan secara lisan dalam bahasa Indonesia yang dimengerti oleh terdakwa dan saksi-saksi. Kalau kedua ketentuan tersebut tidak tidak dipenuhi, maka mengakibatkan batalnya putusan demi hukum.

Pada tahap ini penuntut umum sebagai pihak yang diberi wewenang melakukan penuntutan, diberi kesempatan oleh hakim ketua sidang untuk membacakan surat dakwaan. Apabila pihak terdakwa tidak mengerti tentang isi surat dakwaan yang diajukan kepadanya, penuntut umum atas permintaan hakim ketua sidang wajib memberi penjelasan yang diperlukan.

Terdakwa atau penasehat hukumnya dapat mengajukan keberatan (eksepsi) terhadap surat dakwaan penuntut umum. Keberatan (eksepsi) terdakwa dan penasehat hukum itu meliputi.

\footnotetext{
${ }^{10}$ www.http//tahapan dan proses persidangan 2011,diakses pada Desember 2014

${ }_{11}$ Kitab undang hukum acara pidana, undang-undang no 8 tahun 1981 tentang pemeriksaan persidangan
} 
a.Pengadilan tidak berwenang mengadili ( berkaitan dengan kompetensi absolut / relatif).

b. Dakwaan tidak dapat diterima (karena dakwaaan dinilai kabur / obscuur libel).

c. Dakwaan harus dibatalkan (karena keliru, kadaluarsa atau nebis in idem).

Sesudah pembacaan keberatan (eksepsi) dari terdakwa atau penasehat hukum, hakim ketua sidang memberi kesempatan pada penuntut umum untuk mengajukan tanggapan atas keberatan (eksepsi) yang biasanya disebut replik.[13] Didalam praktek sering juga sebelum menjatuhkan putusan sela hakim ketua masih memberikan kesempatan pada terdakwa / penasehat hukum untuk mengajukan tanggapan sekali lagi yang disebut duplik. Kesempatan yang terakhir ini tidak diatur dalam KUHAP, akan tetapi merupakan kebijaksanaan hakim berdasarkan asas keseimbangan pada pemeriksaan.Atas eksepsi beserta tanggapan-tanggapan tersebut selanjutnya hakim ketua sidang menjatuhkan putusan sela.

Setelah putusan sela diucapkan atau dibacakan hakim ketua menjelaskan seperlunya mengenai garis besar isi putusan sela sekaligus menyampaikan hak penuntut umum, terdakwa dan penasehat hukum untuk mengambil sikap menerima atau akan mengajukan perlawanan.

\section{Sidang pembuktian}

Apabila hakim/majelis hakim menetapkan dalam putusan sela sidang pemeriksaan perkara harus dilanjutkan, maka acara persidangan memasuki tahap pembuktian, yaitu pemeriksaan terhadap alat-alat dan barang bukti yang diajukan. Dari keseluruhanan proses peradilan pidana tahap pembuktian ini sangat penting, karena dari hasil pembuktian ini nantinya akan dijadikan dasar pertimbangan bagi hakim untuk menentukan bersalah atau tidaknya terdakwa dalam putusan ${ }^{12}$.

Bagaimana pentingnya tahap sidang pembuktian ini, digariskan dalam pasal 183 KUHAP yang berbunyi, hakim tidak boleh menjatuhkan pidana kepada seseorang kecuali dengan sekurang-kurangnya dua alat bukti yang sah, ia memperoleh keyakinan bahwa suatu tindak pidana benar-benar terjadi dan bahwa terdakwalah yang bersalah melakukannya.

12 www.http//Sidang Pembuktian 2011,diakses pada Desember 2014 
Pengertian dari pasal 183 KUHAP tersebut dapat disimpulkan, bahwa untuk menentukan salah tidaknya seseorang dan selanjutnya hakim menjatuhkan pidana, maka harus dipenuhi syarat-syarat sebagai berikut:

- kesalahan dipandang telah terbukti jika telah dipenuhi, sekurang- kurangnya dua alat bukti yang sah.

- dan sekurang-kurangnya dua alat bukti yang sah itu hakim memperoleh keyakinan bahwa tindak pidana telah terjadi dan yang melakukan adalah terdakwa. $^{13}$

Dengan memperhatikan bunyi pasal 183 KUHAP, maka jelaslah bahwa KUHAP menganut sistem pembuktian menurut undang-undang secara negatif. Sistem ini merupakan perpaduan antara sistem pembuktian menurut keyakinan hakim (conviction intime) dengan sistem pembuktian menurut undang-undang secara positif (positief wettelijke). Dalam sistem pembuktian menurut undang-undang secara negatif ini, tidak cukup keterbuktian itu hanya didasarkan pada alat-alat bukti yang sah menurut undangundang saja, akan tetapi juga bersamaan dengan itu harus ada keyakinan hakim.

Dengan uraian tersebut dapat disimpulkan, untuk menentukan salah atau tidaknya terdakwa menurut sistem pembuktian menurut undang-undang secara negatif, harus dipenuhi dua komponen:

Pembuktian harus dilakukan atas ketentuan, cara-cara dan alat-alat bukti yang sah menurut undang-undang.

Keyakinan hakim juga harus didasarkan atas atas ketentuan, cara dan alat-alat bukti yang sah menurut undang-undang.

\section{Pembacaan Tuntutan Pidana}

(requisitoir) Apabila sidang tahap pembuktian dinyatakan selesai, maka hakim ketua memberi kesempatan kepada penuntut umum untuk membacakan tuntutan pidana.Tuntutan pidana yang dibuat penuntut umum pada hakikatnya adalah kesimpulan yang diambil dari fakta yang terungkap dipersidangan menurut versi penuntut umum, disertai dengan tuntutan sanksi pidana / atau tindakan yang akan dijatuhkan pada terdakwa.Tuntutan pidana ini diajukan secara tertulis dan setelah

\footnotetext{
13 KUHAP pasal 183
} 
dibacakan segera diserahkan kepada hakim ketua sidang dan turunannya kepada pihak yang berkepentingan. ${ }^{14}$

Oleh karena surat tuntutan pidana dilakukan secara tertulis dan merupakan kesimpulan berdasarkan keseluruhan hasil pemeriksaan di persidangan, maka dengan sendirinya tuntutan pidana tersebut harus disusun kedalam suatu surat tuntutan pidana secara sistematis.

Amar tuntuan yang berisi pernyataan kesalahan terdakwa terbukti atau tidak terbukti, lamanya pidana yang akan dijatuhkan atau pembebasan terdakwa. Selain itu juga hal-hal yang berkaitan dengan barang bukti, penahanan dan lain-lain.Isi dari tuntutan pidana tidak selalu berupa penjatuhan pidana, hal ini tergantung dari hasil pembuktian penuntut umum. Apabila menurut penuntut umum fakta yang terungkap di persidangan memenuhi unsur tindak pidana yang di dakwakan, maka penuntut umum menyatakan terdakwa terdakwa terbukti bersalah dan mengajukan permohonan agar terdakwa dijatuhi pidana. Namun, apabila ternyata fakta di persidangan menunjukkan ada unsur dakwaan yang tidak terpenuhi maka secara objektif penuntut umum harus menyatakan bahwa terdakwa tidak terbukti bersalah dalam tuntutannya harus mengajukan permohonan agar majelis hakim membebaskan terdakwa.

\section{Pengajuan / Pembacaan Nota Pembelaan (pledoi)}

Pengajuan pembelaan ini merupakan salah satu hak yang diberikan kepada terdakwa dalam kaitannya dengan asas praduga tak bersalah (presumption of innocence), disamping hak terdakwa untuk menanggapi setiap keterangan yang diajukan saksi-saksi ${ }^{15}$.Dalam kaitannya dengan prosedur pemeriksaan perkara pidana, maka pembelaan menurut KUHAP adalah merupakan jawaban terdakwa / penasehat hukum atas tuntutan pidana yang diajukan penuntut umum kepadanya.

KUHAP tidak mengatur secara terperinci apa hakikat pembelaan dan apa syarat sahnya suatu nota pmbelaan. Akan tetapi dalam praktek peradilan di Indonesia pembelaan yang diajukan oleh terdakwa secara langsung adalah merupakan pembelaan bebas,artinya pembelaan tersebut mengemukakan sangkalan-sangkalan,tanggapan-

\footnotetext{
${ }^{14}$ www.http//sidang pembacaan surat dakwaan,eksepsi,dan putusan sela 2011,diakses pada Desember 2014

${ }^{15}$ www.http//pengajuan /pembacaan nota pembelaan(pledoi) 2011,diakses pada Desember 2014
} 
tanggapan atas tuntutan penuntut umum yang disertai dengan ungkapan situasi kondisi mengenai dirinya, keluarganya, dan rasa penyesalannya.Sebenarnya itu diajukan dengan tujuan agar tidak dihukum atau sekedar untuk memohon keringanan hukuman.

\section{Sidang Pembacaan Putusan}

Sebagai tahap akhir dari seluruh rangkaian proses persidangan perkara pidana, adalah sidang pengambilan putusan. Sebelum menjatuhkan putusan ini, majelis hakim akan mempertimbangkan segala sesuatunya berdasarkan atas surat dakwaan, segala sesuatu yang terbukti di persidangan, tuntutan pidana, pembelaan dan tanggapantanggapan. Dasar-dasar pertimbangan dalam putusan hakim harus dimusyawarahkan oleh majelis hakim ${ }^{16}$.

\section{Ada tiga kemungkinan putusan hakim ini}

1. Terdakwa dinyatakan bersalah dan dijatuhi pidana, disini terdakwa dinyatakan dalam putusan bahwa perbuatan yang didakwakan jaksa penuntut umum terbukti secara sah dan menyakinkan.

2. Terdakwa dinyatakan bebas dari dakwaan, disini terdakwa tidak terbukti secara sah dan meyakinkan melakukan tindak pidana yang didakwakan.

3. Terdakwa dinyatakan lepas dari segala tuntutan hukum, disini perbuatan terdakwa terbukti, namun bukan merupakan tindak pidana atau terdapat alasan pemaaf pada diri terdakwa.

Setelah majelis hakim menjatuhkan putusan kepada terdakwa dijelaskan hak-hak para pihak terhadap putusan itu. Hakim ketua sidang menawarkan pada terdakwa untuk menentukan sikapnya, apakah akan menyatakan menerima putusan tersebut, menyatakan menerima dan akan mengajukan grasi, menyatakan naik banding atau berpikir-pikir. Hal yang sama juga diberikan kepada jaksa penuntut umum.

Sejak tahun 2009 sampai dengan 2014 terdapat beberapa yang telah diajukan ke Pengadilan dan tiga diantaranya yang telah mendapat vonis dari Hakim.Namun dikarenakan keefektifitasan UU No.21 Tahun 2007 baru bisa diterapkan pada tahun 2008 maka penulis hanya memberikan data putusan kasus Perdagangan Orang pada

\footnotetext{
${ }^{16}$ www.http//Sidang pembacaan putusan, diakses pada Desember 2014
} 
tahun 2008 hingga 2009 di Pengadilan Negeri Pekanbaru dapat dilihat dari Tabel I dibawah ini.

Tabel I.

Putusan Kasus Perdagangan Orang di Pekanbaru

Tahun 2009-2014

\begin{tabular}{|c|c|c|c|}
\hline & ahun & Terdakwa & Hukuman \\
\hline 1 & 009 & i Windi Langi Als Windi & \begin{tabular}{|l} 
Hu Hukuman yang dijatuhkan adalah \\
hukuman pen jar jara 3 tahun,denda \\
Rp.120.000.000(Seratus dua pu puluh juta rupiah
\end{tabular} \\
\hline 2 & 009 & $\begin{array}{c}\text { 3a Badin Als Badit Als } \\
\text { Badin Bin Umar, Dedi } \\
\text { Irawan Als Dedi Bin } \\
\text { Sudin,E.UginSugiono } \\
\text { Bin Partadi }\end{array}$ & $\begin{array}{l}\text { Hukuman yang dijatuhkan masing-masing } \\
\text { adalahHukuman penjara } 5 \text { tahun } 6 \text { bulan dan denda } \\
\text { Rp.120.000.000(Seratus dua puluh juta rupiah) }\end{array}$ \\
\hline 3 & 009 & Da Dahlan Karo-Karo & $\begin{array}{c}\text { Hukuman yang dijatuhkan adalah } 3 \text { tahun penjara } \\
\text { dan denda Rp.120.000.000(seratus dua puluh juta } \\
\text { rupiah) }\end{array}$ \\
\hline
\end{tabular}

Sumber : Panitera PN Pekanbaru 2009-2014

\section{Posisi Kasus}

Agar lebih jelas penulis menyajikan satu kasus yang telah diputus oleh Pengadilan Negeri Pekanbaru,dengan perkara:dengan sengaja melawan hukum melakukan Tindak Pidana Perdagangan Orang.Dengan nomor Perkara:333/ Pid./B/2009/PN.PBR, sebagai pembahasan terhadap tindakan represif dari Pengadilan. Namun sebelumnya penulis akan menjelaskan secara singkat untuk putusan kasus perdagangan orang pada tahun 2009

Analisis Kasus Dakwaan Penuntut Umum Dakwaan Penuntut Umum disusun dalam bentuk dalam bentuk dakwaan alternatif, dakwaan kesatu menggunakan Pasal 2 ayat (1) UU RI No.21 Tahun 2007 tentang PTPPO, yakni pelaku telah melakukan perekrutan, 
pengangkutan, penampungan, pengiriman, pemindahan, atau penerimaan seseorang dengan posisi rentan yang dialami oleh korban kemudian memberikan bayaran atau manfaat walaupun memperoleh persetujuan dari orang yang memegang kendali atas orang lain.

Melihat posisi kasus di atas maka penulis sependapat dengan pasal 2 ayat (1) UU RI No.21 Tahun 2007 tentang PTPPO yang didakwakan Penuntut Umum kepada Terdakwa ditempatkan sebagai dakwaan alternatif pertama, sebab bila didalam persidangan terbukti dan secara meyakinkan terdakwa bersalah maka hukuman penjara yang diancamkan terhadap Terdakwa bisa ditambah atau lebih berat.

Mengenai tuntutan dari Penuntut Umum sendiri yakni menjatuhkan pidana penjara selama 5 (lima) tahun dengan dikurangi selama Terdakwa berada dalam tahanan sementara dan denda sebesar Rp 120.000.000,00 (seratus lima puluh juta rupiah) subsidair 6 (enam) bulan kurungan adalah sangat ringan mengingat dampak yang ditimbulkan dari perbuatan Terdakwa sangat merusak masa depan korban, moral, fisik, psikis, merendahkan harkat, derajat dan martabat perempuan sebagai makhluk yang mulia dihadapan Tuhan serta bertentangan dengan Hak Asasi Manusia, seharusnya hukuman yang dituntutkan kepada Terdakwa lebih berat sehingga dapat memberikan rasa jera bagi Terdakwa.

Putusan Hakim Sebelum membahas tentang putusan terlebih dahulu dijelaskan kekuasaan kehakiman dan definisi hakim berdasarkan berapa peraturan perundang-undangan yang berlaku. Menurut Pasal 31 Undang-Undang No. 4 Tahun 2004 Tentang Kekuasaan Kehakiman, hakim adalah pejabat yang melakukan kekuasaan kehakiman yang diatur dalam undang-undang. Sedangkan menurut Pasal 1 angka 8 KUHAP, hakim adalah pejabat peradilan negara yang diberi wewenang oleh undang-undang untuk mengadili. Pasal 1 angka 9 KUHAP menjelaskan bahwa "mengadili adalah serangkaian tindakan hakim untuk menerima, memeriksa dan memutus perkara pidana berdasarkan azas bebas, jujur, dan tidak memihak di sidang pengadilan dalam hal dan menurut cara yang diatur dalam undangundang.

Kekuasaan kehakiman adalah kekuasaan negara yang merdeka untuk menyelenggarakan peradilan guna menegakkan hukum dan keadilan berdasarkan Pancasila, demi terselengaranya negara hukum Republik Indonesia (Pasal 24 UUD 1945 dan Pasal 1 UU Nomor 48 Tahun 2009 tentang Kekuasaan Kehakiman). Penyelenggaraan kekuasaan kehakiman dilakukan oleh sebuah Mahkamh Agung dan peradilan di bawahnya yaitu : (1) 
lingkungan peradilan umum; (2) lingkungan peradilan agam; (3) lingkungan peradilan militer; (4) lingkungan peradilan tata usaha negara, serta oleh Mahkamh Konstitusi (Pasal 24 ayat (2) dan Pasal 2 UU Nomor 49 Tahun 2009 tentang Kekuasaan Kehakiman.

Selanjutnya definesi putusan pengadilan sebagaimana dibunyikan dalam Pasal 1 butir 11 KUHAP yaitu pernyataan hakim yang diucapkan dalam sidang pengadilan terbuka yang dapat berupa pemidanaan atau bebas atau lepas dari segala tuntutan hukum, dalam hal serta menurut cara yang telah diatur dalam undang-undang ini. Mengenai penjatuhan putusan pengadilan tergantung hasil mufakat musyawarah hakim berdasar penilaian yang mereka peroleh dari surat dakwaan dihubungkan dengan segala sesuatu yang terbukti dalam pemeriksaan di sidang pengadilan.

Adapun faktor-faktor yang dapat mempengaruhi hakim dalam membuat dan mengambil keputusan, yaitu:

1.Faktor pengacara, misalnya penampilan dan gaya bicara yang meyakinkan juga memberikan pengaruh terhadap putusan hukuman;

2.Faktor terdakwa, misalnya jenis kelamin terdakwa, ras dan kemampuan Bicara;

3.Faktor hakim itu sendiri, misalnya adalah kepribadiannya, intelegensi

suasana hati; dan

4.Faktor opini publik yang tertulis dalam media massa ketika sidang tengah berlangsung ${ }^{17}$.

Demikian Majelis Hakim yang mengadili perkara sangat terlihat jelas bahwa mempertimbangkan tujuan penjatuhan pidana bukanlah semata-mata sebagai suatu pembalasan dendam belaka sebagai akibat dari perbuatan yang telah dilakukan oleh Terdakwa, akan tetapi lebih bertujuan untuk memberi efek jera sekaligus proses pembelajaran bagi diri Terdakwa agar Terdakwa tidak lagi mengulangi tindak pidana serupa atau melakukan tindak pidana yang lain dikemudian hari, sehingga menurut pidana yang dijatuhkan telah memenuhi tujuan pemidanaan yang harus bersifat prefentif, korektif, dan edukatif maka pidana penjara yang dijatuhkan dalam amar putusan ini telah tepat dan memenuhi rasa keadilan, baik secara yuridis, sosiologis.

\section{KESIMPULAN}

\footnotetext{
${ }^{17}$ AntoniusSudirman,SH,MH Hati Nurani Hakim dan Putusannya,penerbit:Citra Aditya Bakti,2007 HIm 55
} 
1. Tinjauan yuridis penegakan hukum tindak pidana perdagangan perempuan (trafficking in women) di wilayah Pengadilan Negeri Pekanbaru, yaitu dilakukan dengan dua metode yakni dengan tindakan preventif dan tindakan represif, selanjutnya dalam pemberian putusan dilakukan dengan pertimbangan Yang Bersifat Yuridis dan Pertimbangan Yang Bersifat Non Yuridis. Dari uraian tersebut mencermintkan bahwa penerapan perlindungan hukum terhadap perdagangan perempuan di Pengadilan Negeri Pekanbaru perpegang pada asas hukum. dalam konteks hukum pidana, asas hukum harus mewarnai baik hukum pidana materiil, hukum pidana formil, maupun hukum pelaksanaan pidana Asas manfaat, Asas keadilan, Asas keseimbangan dan Asas kepastian hukum.2.Masyarakat Kota Pekanabaru yang

2. yang terjerat kasus tindak pidana perdagangan orang, baik sebagai pelaku maupun korban juga cukup banyak, sehingga Pengadilan negeri masih menerima kasus perdagangan wanita dalam kasus tersebut. Proses penyelesaian yang dilakukan oleh Pengadilan negeri Pekanbaru dengan cara memeriksa dan mengadili para pelaku tindak pidana perdagangan orang dan memberikan sanksi sesuai Peraturan yang berlaku guna memberantas kejahatan perdagangan orang diwilayah Pekanbaru.

\section{DAFTAR PUSTAKA}

Amiruddin. M dan Zaenal Asikin. 2004. Pengantar Metode Penelitian Hukum. Jakarta: PT. Raja Grafindo Persada

Andi Hamzah, 1993, Sistem Pidana dan Pemidanaan Indonesia, Jakarta: Pradnya Paramita

A. Hamzah dan Siti Rahayu, 2000 Suatu Tinjauan Ringkas Sistem Pemidanaan di Indonesia Jakarta: Akademika Pressindo

Adami Chazawi. 2002. Pelajaran Hukum Pidana Bagian I. Jakarta: PT.Raja Grafindo Persada

Arif Gosita, 2004, Masalah Korban Kejahatan (kumpulan karangan), Jakarta : Edisi ke tiga, PT. Bhuana Ilmu Popular Kelompok Gramedia 
Antonius,Sudirman,SH.MH.2007,Hati Nurani Hakim dan Putusannya Jakarta:Citra Aditya Bakti

Christine S.T. Kansil, 2004, Pokok-pokok Hukum Pidana, Jakarta: Pradnya Paramita

E. Utrecht, 1958, Hukum Pidana I, Jakarta:Universitas Jakarta

Ibrahim. J. 2006. Teori dan Metedologi Penelitian Hukum Normatif. Malang: Bayumedia Publishing

IOM Indonesia, 2006, Fenomena Trafiking Manusia dan Konteks Hukum Internasional, Jakarta

J.E. Sahetapy, 1979, Ancaman Pidana Mati Terhadap Pembunuhan Berencana, Bandung: Alumni

Khudzaifah Dimyati. 1999, Teorisasi Hukum, Surakarta: Muhammadiyah University Press

Koeswadji, 1995, Perkembangan Macam-macam Pidana Dalam Rangka Pembangunan Hukum Pidana, Cetakan I, Bandung: Citra Aditya Bhakti

Muladi dan Barda Nawawi, 1992, Teori dan Kebijakan Pidana. Bandung: Alumni

R. Soesilo, Kitab 1994, Undang -Undang Hukum Pidana (KUHP) Serta Komentar-Komentar Lengkap Pasal demi pasal, Bogor: Poltitea

Satjipto Rahardjo, 1986, Ilmu Hukum, Bandung: Alumni

Satjipto Rahardjo, 1993 Masalah Penegakan Hukum, Suatu Tinjauan Sosiologis, Sinar Baru: Bandung

Soekanto. Soerjono. 1988. Pengantar Penelitian Hukum. Jakarta: UI Perss, 1988 2005, Faktor-faktor yang mempengaruhi Penegakan Hukum, PT Rajagrafindo Persada: Jakarta

Sulistyowati Irianto, et.al, 2007. Perdagangan Perempuan Dalam Peredaran Narkotika. Jakarta: Yayasan Obor Indonesia 
S.R Sianturi, 2002, Asas-asasHukumPidana di Indonesia danPenerapannya, Jakarta: StoriaGrafika.

Kementerian Kordinator Bidang Kesejahteraan Rakyat, 2005, Penghapusan Perdagangan Orang di Indonesia, Jakarta

W.A. Bonger, 1981, Pengantar Tentang Kriminologi. Jakarta: PT Pembangunan Ghalia Indonesia

W.A Bonger, 2003 Pengantar Tentang Kriminologi, Jakarta: Pustaka

Febriana, 2012 "Penegakan Hukum Terhadap Tindak Pidana Pencabulan Anak di Wilayah Hukum Polisi Sektor Siak Hulu", skripsi, Fakultas Hukum Universitas Riau, Pekanbaru,

Zaelani Tammaka, 2003, Menuju Jurnalisme Berperikemanusiaan Kasus Trafficking dalam Liputan Media di Jawa Tengah dan DIY, Aji Surakarta, Surakarta

Rm.Sutikno Mertakusumo,2008,Kemandirian hakim ditinjau dari struktur lembaga kehakiman,Jakarta

Undang-undang Dasar Negara Republik Indonesia Tahun 1945

KUHP (Kitab Undang-undang Hukum Pidana)

Undang-undang Nomor 21 Tahun 2007 tentang Tentang Pemberantasan Tindak Pidana Perdagangan Orang sebagaimana dicatat dalam Lembaran Negara Republik Indonesia Nomor 4720. 